\title{
Auditors' Professional Experience and its Effect in Reducing the Impact of Audit Problems - An Empirical Study in the Private Offices of Audit in Iraq
}

\author{
P.A.Dr. Munir Shaker Mohammed \\ Al-Kunooz University College -Basra-Iraq \\ Department of Business Administration - Basra - Iraq
}

\section{Abstract:}

This study aims to identify the benefits of the auditor's professional experience in reducing the impact of audit's problems. The elements representing the professional experience of the auditor were identified by three elements and considered representative of the independent variables of the study, namely: (1) the period of the auditor's professional experience, (2) the level of qualifications that the auditor holds, (3) the nature of the auditor's specialization. It also diagnosed the problems that the auditor faces in his work based on previous studies and through polling the auditors' opinions. These Problems are : (1) Problems related to laws and legislation, (2) Problems related to professional associations and colleagues, (3) problems related to clients and managements, (4) behavioral aspects of Colleagues and social pressures.. The research uses the questionnaire method to gather the necessary information and data, and the statistical methods are used to analyze the information gathered. The results of the statistical tests showed that there is a positive linear relationship between the three independent variables and the four problems the auditor faces in his professional work. The analysis of the results indicates that the first variable(The length of the professional experience) takes the priority in terms of its impact on the problems faced by the auditor.

Key Words:

Auditors' Professional Experience, Audit Problems, Private Sector Audit, Iraqi' Professional Auditing Problems

\section{Introduction}

Audit profession occupies great importance in all societies, especially those that adopt audit reports as one of the main sources in making economic decisions and financial analyzes provided by various departments. In some countries, the progress of audit profession was considered as an important criterion for progress, as it relates to awareness of the public interest of the state and the protection of its various resources. Therefore, the ability of the auditor to maintain his impartiality and professional efficiency greatly contributes to raising the value of the reports he submits to the community. However, this is not always an easy case for many reasons Including of these reasons the auditor himself who may not be consistent with the required level of competence or experience that enables him to contribute effectively to the expected goal of protecting the interests of the state and society. This is due to two basic elements that limit his ability, the first is the nature of the problems he faces in his work, and the second is his ability to face these problems and how he can limit their impact on his work and his efficiency. Current study sought to examine this problem that affects many countries, including Iraq.

Therefore, the research is directed to study and analyze an important aspect of this framework, which is the professional auditor's experience and its role in reducing their negative effects on his work. The main components of the auditor's professional experience were identified as three elements (variables) mentioned above. The problems that the auditor faces that limit his efficiency and impartiality were also identified with four problems mentioned above. The research included a field study through which the opinions of a group of auditors were sought to discuss the relationship between the professional experience of auditors and the problems he faces in his work. A set of conclusions and recommendations were identified and discussed accordingly. 


\section{Research Structure:}

The research includes four parts, the first of which includes the research methodology, the second one includes the theoretical side and previous studies, the third topic includes the practical and applied side of the research, analysis and discussion of the information collected in the field and drawing the results of the field side. In the fourth topic , accordingly the conclusions and recommendations were identified.

\section{$\underline{\text { Research Methodology }}$}

This topic includes the following aspects:

(1) A statement of the research problem that the research seeks to clarify and solve.

(2) Research objectives that the study seeks to achieve through clarifications, discussions, applications and practical analysis of the different points.

(3) Research hypotheses that represent the foundations the research assumes and seeks to prove or to reject and which contributes to achieving the objectives of the research,

(4) Research contribution, which represents an explanation of what the research can contribute in terms of proving facts related to the scientific aspect of audit work,

(5) Collecting information which clarifies the sources and methods that the researcher followed to collect theoretical and practical information to prepare the research,

(6) Research methods and tools, which explain the methods and tools used by the researcher to analyze the data and information to research the final results.

The following is a brief discussion of each of the above mentioned points:

\section{First: Research Problem:}

Due to the importance of the auditing profession and its reports, it has become necessary for the auditor to have the competence and experience sufficient to produce reliable reports. For this it is necessary to diagnose the factors that limit and weaken this efficiency. Within this framework, a basic set of problems that limit this experience and competence of the auditor (which represent negative aspects within this framework) were identified, and the components of the aspects of experience that enable him to face these problems (which represent positive aspects) were also identified. The research seeks to determine the nature of the relationship and the mutual influence between the elements of experience (positive aspects) that the auditor enjoys and the problems the auditor face (negative aspects). Therefore, the research problem can be summarized by the following questions:

(1) What is the effect of the long period of auditor's experience in reducing the impact of the problems he faces in his professional work?

(2) What is the effect of the auditor's academic qualification level on reducing the problems he faces in his professional work?

(3) What is the effect of the nature of the academic specialization of the auditor in reducing the problems that he faces in his professional work?

(4) What is the priority of the elements (variables) mentioned in limiting the impact of the mentioned problems on his professional work?

\section{Second: Research objectives:}

The research aims to achieve the following objectives:

1-To Clarify the importance of auditor's professional experience in dealing with the problems he faces and identify the basic elements of this experience.

2- To Clarify the extent to which the length of auditor experience has an effect in supporting him to reduce the impact of the professional problems he faces . 
3- To clarify the extent to which the academic scientific level of the auditor can influence his ability to reduce the impact of professional problems he faces. Academic level means whether the auditor holds a bachelor, master, or doctorate degrees as well as his professional qualifications.

4- To clarify the extent to which the nature of the auditor's specialization can influence his ability to reduce the impact of the problems he faces. The nature of the specialization means whether the basic auditor certificate is in accounting, financial and banking sciences, or economics, and so on.

\section{Third: Research Hypothesis:}

For the purpose of achieving its indicative goals, the research lays the following basic hypothesis:

H0: There is a positive meaningful relationship between the auditor professional experience and the degree of reduction of the effect of the professional problems he face. i.e., as the level of auditor's experience increase, the reduction in the problems' effect increase. "This basic hypothesis is divided into the following sub-hypotheses:

HO1: There is a statistically significant relationship between the length of the auditor's experience and the degree of reduction in the effect of the professional problems.

HO2: There is a statistically significant relationship between the academic qualification level of the auditor and the degree of reduction of the effect of the professional problems.

HO3: There is a statistically significant relationship between the nature of the auditor's academic specialization and the degree of reduction in the effect of the professional problems.

\section{Fourth: Research Contribution:}

The research contributes in demonstrating the potential of the elements of professional experience in reducing the problems facing the auditor in his work and supporting him in reducing their effects on his impartiality and work efficiency. This contribution in explaining the influencing elements and the priorities of the effects they produce will help in guiding the thought of the legislator and the professional bodies to develop those elements in the auditor's work and to provide the supporting pillars for them., whether in the area of education, training courses, or setting the necessary standards .

\section{Fifth: Gathering Information:}

Information and theoretical data necessary for the study were collected through the library, journals, Internet, and published research. Empirical information was also collected through a questionnaire prepared for this purpose and through interviews with many auditors working in private offices.

\section{Sixth: Research Tools:}

Questionnaire method is used to gather the required information and data from a sample of (60) auditors selected randomly from audit offices located in Baghdad and Basra Cities out of (161) specialized audit offices distributed in Iraqi's cities. (48) forms of questionnaires were collected out of (60), i.e., $80 \%$.

The questionnaire included (3) axes, each axis included (20) questions, these questions are distributed on four parts each one refer to a particular problem, i.e., (5) questions for each problem . Each axis is linked with one of the three independent variables (elements) of the (personal professional experience). Each axis indicates the relationship of each of the three independent variables with the set of the questions associated with each of the four problems

\section{Theoretical Part and Previous Studies}

Several studies have dealt with the problems faced by auditors in their work, especially in recent years, the effect of these problems on the auditor's impartiality, his efficiency, objectivity and integrity of the reports provided. Some studies have discussed how to reduce this effect and what are the methods and means that enable him to reduce the impact of these problems on his performance and efficiency. However, most of these studies were concerned with 
identifying the problems that the auditor faces in his work, the nature and effect of these problems, and how to confront them (Durgham, 2009), (Al-Amro and Anqari, 2007), (Al-Dalahma, 2006), (Basma Faleh Al-Nuaimi, 2020), (Thabet and Abdel Wahid, 2014) ((Mutter 1990); Mutter, 1994); (Al-Bashir, 2000), (Al-Khuffash, 1994), (Miala, 1999); (Al-Halabi, 1999); (Al-Fadil and Jajawi, 2000) (Jawdat, 2000); (Muhammad Saeed, 2000)), (Helps, 1994); (Chinook, 1995); (Ainon, 1996), (Marhoon, 2009). However, only few of these studies have tried to identify the effect of the personal experience of auditors on facing these problems.

\section{Evolution of Audit Profession in Iraq:}

The development of audit profession in Iraq was affected by the development of Iraqi legislation during the twentieth century. Iraqi legislations and laws were affected by the British ideology which occupied Iraq since the beginning of the twentieth century and organized many activities according to its directions. Therefore, we find that this effect was evident in most of the features of auditing and its institutions in Iraq. The British audit offices were in control of the profession of public auditing in Iraq during the period prior to 1958 . Shortly afterwards, the system of government in Iraq changed to Republican system and a phase of change and development begun . For this, three stages of the profession's development can be distinguished in Iraq, starting with the application of the Indian Companies Act in 1919, which was applied in India and then followed by the British Empire. This law was originally derived from the British law, and therefore the Iraqi legislation at the time was consistent with British legislation, including audit legislations. These legislations clarified the rights and duties of the auditor, and stipulated that the auditor should be a graduate of a British institute, which required the auditor to obtain a British Chartered Accountant certificate of audit. After that, 1957 law was issued, which was also affected by the law of 1919. After that, Iraq witnessed the issuance of a national audit legislation that abolished the law of 1957, and the process of development in legislation related to the function of auditing and taking into account the working conditions of the Iraqi regulatory bodies continued. University academic institutions and Iraqi professional institutes began to qualify auditors, to reach after that the stage of issuing the system of practicing the profession of auditing in 1983. Then unified accounting system was issued which was required to be applied at all levels and for supervisory reasons (Al Douri, 2014).

\section{Previous Studies :}

Many studies were published about the problems faced by professional auditors discussing the nature and dimensions of the problems facing auditing profession. Some of these studies are:

\section{1- Morhoun (2012):}

"The relationship between the problems of auditing profession and the development of this profession in Iraq, "an analytical practical study":

This study discussed the relationship between the nature of the problems facing audit profession, and the development of this profession in Iraq. The researcher reached a conclusion that auditors lack a commitment to international auditing standards and the limited number of offices that adhere to sound professional behavior. The study also indicated the fact that many auditors do not have the experience required to practice the profession properly.

\section{2- Al-Khater\& Al-Al-Attar Study, (2009):}

"Factors Affecting Determining Auditor Fees, An Empirical Field Study on the State of Qatar":

This study sought to identify the factors affecting the determination of audit fees. The study used a sample of auditors in Qatar to explore their views on the extent of the impact of these factors in determining the wages for audit process.

\section{3-Al-Omar and Al-Anqari, (2007):}

"Evaluation of the Effectiveness of the basics of Organizing the Auditing Profession in the Saudi Arabia in Facing Contemporary Problems and Challenges": 
This study aimed at assessing the foundations of auditing profession in Saudi Arabia, which include professional standards, professional conduct rules, professional tests, continuing education programs, and programs for monitoring the quality of professional performance by measuring the effectiveness of such basics in dealing with the problems and challenges faced by the auditors in Saudi Arabia. The study concluded that there is no absolute agreement between the auditors on one side and the parties related to the profession to enact another side about the extent of their knowledge of the problems and challenges they face .

\section{4- Al-Halaby, (2006):}

This study aimed to know the nature of the problems that affect the auditing profession and that the auditor faces during his audit of the Syrian private sector companies and used the questionnaire methodology to access the information that the researcher needs in his study. The researcher concluded that job behavior by departments and clients and by colleagues in the profession is the most obvious problem within this framework.

\section{5-Coram (2002):}

At the global level, a study in Australia identified problems facing auditors that threaten the auditor's impartiality and limit their important competence. Problems identified by the study are : (1) weak scientific and professional qualification, (2) poor supervision of the profession as a result of weak legislation regulating the profession, (3) lack of auditors keeping up with developments in the profession.

According to these studies the main problems of audit in Iraq, however, the same in other Arab countries, can be summarized as:

1- Problems arising due to legislation, laws and regulations.

2- Problems arising due to professional associations and professional colleagues.

3- Problems related to the relationship with clients and client and Management.

4- Problems arising due to behavioral aspects and social pressures.

Despite the importance of these studies, which covered many aspects of audit work and how to address them to reduce their impact on audit efficiency, the personal professional experience that auditors enjoy have not been sufficiently studied to know their impact in reducing these problems. Also, the components of experience, such as the length of personal professional experience of auditors, their scientific qualifications and nature of specialization have not been given adequate attention to know how could be benefited to reduce the bad effect of these problems . These elements (variables) have been identified based on many studies as personal experience variables which can be benefited to face the negative effect of audit problems. (Mohammed \& Noor, 2003).

\section{Field study}

\section{Data Collection Method:}

Empirical data and information of the study have been obtained through the interviews made with auditors as well as preparing a questionnaire form to obtain first hand data. Information obtained is concentrating on auditors opinions about the importance of the auditors' professional experience in supporting their ability to face the four problems identified by the research. The questionnaire includes (3) basic axes, each axis indicates the relationship of each of the three study variables (experience elements) with the fourth basic problems facing audit. Therefore, each axis contains (4) parts. Each part indicates the relationship of the variable to one of the problems. Each axis, therefore, includes (20) questions divided between the four problems on an average of (5) questions each. Total questions in the form are, therefore, (60) questions. The auditors are asked to explain their opinion about the extent of their conviction about the effect of the first, second or third variable in reducing the impact of the problems the auditor faces (Appendix No. (1) - Table No. (1).

The research sample of auditors is (60) auditors distributed randomly among audit offices in Baghdad and Basra Cities, out of (161) audit offices scattered in the country. The questionnaire form was distributed on auditors, (48) forms were collected which represent $80 \%$ of the distributed forms. Likert measure is used to classify the answers 
which includes (5) levels of answers. Two additional levels were added to the questionnaire in Table No. (1) Appendix No. (1), one is used for calculating weighted average rate and the other for "standard deviation" of the answers of each question. The five levels of the questionnaire form refer to the auditors' answers, which indicate the degree of auditor's conviction in the importance of the (variable) element in reducing the impact of the problem on auditors. The weighted average of the answer of each level of the form and for each question was calculated by multiplying the number of answers to any question by the weight of the field it represents. For example, the number of answers is multiplied under the field "completely agree" in (5) and the number of answers in the second level is multiplied by the number (4) and so on for the rest of the level.

\section{First Part:}

\section{$\underline{\text { Results Analysis }}$}

\section{Analysis of Personal Information of the Sample:}

This includes the analysis of : (1) Sample years of experience, (2) sample scientific qualification, (3) the scientific specialization.

\section{(1) Years of Experience:}

Table No. (1)-Appendix (1) indicates that about $75 \%$ of auditors have long period of experience that enable them to give valid opinion about the benefit obtained by auditors in facing the professional problems of his work. The significance of the of the level of scientific degree as well as the nature of the scientific qualifications the auditor have also been represented in the sample given a total of $25 \%$. This selection of the sample gives the responses more significance than the case when the majority of the sample was from the low level experience of auditors. Table (1) shows the percentages of the sample levels as regards the experience length.

Table (1)

\section{Sample Distribution According To Experience Years}

\begin{tabular}{|l|l|l|l|}
\hline Categories of experience years & No. of Auditors & $\%$ & Accumulated $\%$ \\
\hline $1-5$ years & 12 & $25 \%$ & $25 \%$ \\
\hline $6-10$ years & 18 & $37.5 \%$ & $62.5 \%$ \\
\hline $11-$ more & 18 & $37.5 \%$ & $\% 100$ \\
\hline Total & 48 & $100 \%$ & \\
\hline
\end{tabular}

(2) Level of Academic qualification: The percentages indicated by Table No. (2) show that the bachelor's degree is considered as forefront of the qualifications that most of the sample members possess . However, the part of the sample has good level of academic qualification where some of them have High Diploma which is over than the Bachelor degree. It means that $18 \%$ of the sample have a level equivalent to Master Degree as well as $12.5 \%$ of the sample has Master Degree and Doctorate. It should be mentioned that all the auditors in the sample have a professional study of two years and more after they finish their academic study doing courses in auditing and control in order to be public auditors. This reflect a high level of qualifications enjoyed by the sample auditors which enable them to give valid responses about the study questions produced by the questionnaire form. 
Table (2)

\section{Sample Distribution according to Scientific Qualification}

\begin{tabular}{|l|l|l|l|}
\hline Level of Scientific Qualification & No. & \% & Accumulated \% \\
\hline Bachelor & 24 & $50 \%$ & $50 \%$ \\
\hline High Diploma & 18 & $37.5 \%$ & $87.5 \%$ \\
\hline High Studies & 6 & $12.5 \%$ & $100 \%$ \\
\hline & 48 & $100 \%$ & \\
\hline
\end{tabular}

3) Scientific Specialization: Table No. (3) shows that specializations of the sample. As the Table reflects the majority of the sample is from accounting specialization $32 \%$ as well as a percentage of $11 \%$ from finance and economy which is very close specialization to accounting. This means that the majority of the sample is from the concerned specialization to accounting and thus it can give a value to the responses for its close relation to the specialization needed for the study.

Table (3)

Sample Distribution According To Scientific Specialization

\begin{tabular}{|l|l|l|l|}
\hline Scientific Specialization & No. & $\%$ & Accumulated \% \\
\hline Accounting & 32 & $66.7 \%$ & $66.7 \%$ \\
\hline Economic \& Finance & 11 & $22.9 \%$ & $89.6 \%$ \\
\hline Management \& Law & 5 & $10.4 \%$ & $\% 100$ \\
\hline Total & 48 & $\% 100$ & \\
\hline
\end{tabular}

\section{The Second Part:}

Analysis of theinformation Related to the Questionnaire :

The second Part of the form includes information about the sample's response to the questionnaire form about their opinion as regards the professional experience and its effect on the auditing problems. This part includes (3) sections, each of them includes (20) questions related to auditing problems. These sections are:

First: Auditors attitude towards the impact of the length of auditors experience on audit problems.

Second: Auditors attitude towards the impact of level of auditors' qualifications on audit problems

Third: Auditors attitude towards the impact of nature of auditors specialization on audit problems.

\section{General analysis of the answers:}

From the general review of Table No. (1) Appendix (1), we find that the weighted average of the results of all the answers indicates the sample's conviction that all three elements of experience have a positive effect in reducing the impact of all the problems that the auditor faces. The weighted rates for all the sample answers and for all variables ranged between (3.083) for the sequence question (51) for the third variable - the third problem and (4.7083) for the sequence question (1) - the first variable - the first problem. In comparison with the mean level of the values (weights) of the five fields of the answer, which is (3) i.e., $((1+2+3+4+5) / 5)$, 
We find that the weighted rates indicated by the research indicated above exceed the average rate in the positive effect, and it gives the auditor the ability to face the practical problems that he faces and enables him to reduce their negative impact on his competence as an auditor.

For measuring the standard deviation, we use the Standard Deviation formula shown below (Lyman, 1988, p. 48):

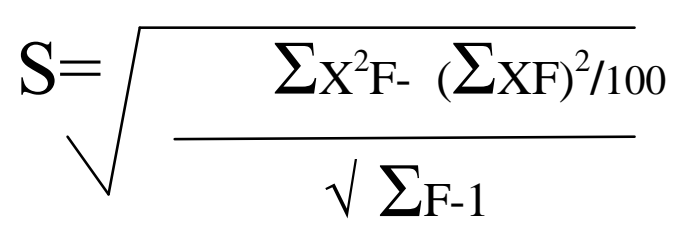

The analysis indicates that the standard deviation for all the answers of the questions is limited between (1.0962) for the first question, the first variable, and (1.494) for the eighth question - the first variable. Therefore, all the standard deviation rates fall within the acceptable framework for the deviation of the answers from Its arithmetic mean, which indicates its objectivity and gives the necessary credibility answers.

\section{Detailed analysis of the answers: \\ 1-Calculating The Rates:}

For the purpose of clarifying the sample response trends and the likelihood of the auditors' professional experience variables in reducing the impact of the problems they face, according to the conviction of the research sample, Table No. (2) below has been prepared that summarizes the results and data of Table No. (1) - Appendix (1). Table (2) shows the rates of impact of each of the three variables of experience on each of the auditing problems, expressed in percentages.

The rates indicated in the table show the weighted figures through multiplying the figure of responses by the weight of level, i.e., 5, 4,3,2,1. and collecting level $(1+2)$ for approval and levels $(4+5)$ for non approval .

The approval rate (the first levels) of Table No. (2) indicates the rate of the sample's conviction about the effectiveness of the three independent variables in facing each one of the problems according to the sequence of these problems. The non-approval rate in Table 2 indicates that the sample is not satisfied with the effectiveness of the variable in facing the four problems.

Therefore, the approval rate indicated in Table (2) represents the average answer to the five questions of the first problem, So that the same for the non-acceptance rate. That is, the first acceptance rate (0.8954), for example, represents the ratio of the relationship of the first variable (length of experience) with the five questions of the first problem (Table 1 Appendix 1), and so on for the rest of the approval and non-approval rates for the three variables with the problems associated with them.

Table No. (2)

General Approval and Disapproval Rates about the Variables of The Study

\begin{tabular}{|c|l|c|c|}
\hline Sr. & \multicolumn{1}{|c|}{ The Variable } & Approval Rate & Disapproval Rate \\
\hline 1 & $\begin{array}{l}\text { The average percentage of the sample's approval (APSA) of the } \\
\text { effect of the first variable (experience period) in reducing the effects } \\
\text { of the first problem }\end{array}$ & 0.8954 & 0.02355 \\
\hline 2 & $\begin{array}{l}\text { (APSA) of the effect of the first variable in reducing the effects of the } \\
\text { second problem }\end{array}$ & 0.719375 & 0.063482 \\
\hline 3 & $\begin{array}{l}\text { (APSA) of the effect of the first variable in reducing the effects of the } \\
\text { third problem }\end{array}$ & 0.829551 & 0.055417 \\
\hline 4 & $\begin{array}{l}\text { (APSA)of the effect of the first variable in reducing the effect of the } \\
\text { fourth problem occurrence }\end{array}$ & 0.812603 & 0.06366 \\
\hline
\end{tabular}




\begin{tabular}{|c|l|c|c|}
\hline 5 & $\begin{array}{l}\text { (APSA) of the effect of the second variable (the nature of the } \\
\text { qualification) in reducing the effects of the occurrence of the first } \\
\text { problem }\end{array}$ & 0.65435 & 0.122494 \\
\hline 6 & $\begin{array}{l}\text { (APSA)of the effect of the second variable in reducing the effects of } \\
\text { the occurrence of the second problem }\end{array}$ & 0.681801 & 0.100869 \\
\hline 7 & $\begin{array}{l}\text { (APSA) of the effect of the second variable in reducing the effects of } \\
\text { the third problem }\end{array}$ & 0.720775 & 0.089439 \\
\hline 8 & $\begin{array}{l}\text { (APSA)of the effect of the second variable in reducing the effects of } \\
\text { the fourth problem }\end{array}$ & 0.691614 & 0.090001 \\
\hline 9 & $\begin{array}{l}\text { (APSA)of the effect of the third variable (the nature of specialization) } \\
\text { in reducing the effects of the occurrence of the first problem. }\end{array}$ & 0.786194 & 0.081512 \\
\hline 10 & $\begin{array}{l}\text { (APSA)of the effect of the third variable in reducing the effects of the } \\
\text { occurrence of the second problem }\end{array}$ & 0.717307 & 0.083783 \\
\hline 11 & $\begin{array}{l}\text { (APSA)of the influence of the third variable in reducing the effects of } \\
\text { the third problem }\end{array}$ & 0.668619 & 0.112494 \\
\hline 12 & $\begin{array}{l}\text { (APSA)of the effect of the third variable in reducing the effects of the } \\
\text { fourth problem }\end{array}$ & 0.666153 & 0.131805 \\
\hline
\end{tabular}

\section{2- Results Analysis :}

Reviewing the approval rates in Table (2) for rows (1-4), we find that it indicates that the sample rate is (0.8954). That is, the sample is convinced that the period of professional experience of auditors, the longer $i$ is, the more it reduces the bad effect of the problems he faces, and helps him reducing their impact on his efficiency. On opposite, the shorter the experience is, the greater of probability that he will face the problems.

\section{1- Analysis of the First Variable Rates:}

The results of the answers in Table No. (2) indicate that the average of the research sample's conviction about the importance of the first variable in reducing the impact of the problems related to laws and legislations he face is (0.8954), while the rate of lack of conviction is $(0.02355)$. These percentages indicate that the majority of the sample believes that the length of the auditor's professional experience represents an important element in reducing the effect of the first type of the problems he faces. The majority of auditors we met believe that the period of auditors experience represents the auditor's previous experiences with rules and regulations. It gives the auditor the idea of how to behave against each case facing him. It has been clarified that many auditors find in the long period of professional experience an important element in examining the experiences that award him experience in dealing with this type of problems and other problems.

Returning to Table No. (2) to study the results of the relation between variable (1) and Problems No. (2) we find that the rate of the conviction that the effect of the first variable (length of experience) in providing the ability to face problems of the second type (problems with professional associations and professional colleagues) is (0.719375), while the rate of weak conviction is $(0.063482)$. This means that there is a high auditors approval among the sample that the long period of auditor's experience enables him to face the problems of this nature and reduce their effects on his efficiency and neutrality, because the long experience enables him to see similar experiences and provides him with the knowledge of how to behave in such cases.

This high conviction of the importance of the first independent variable in providing the auditor's ability to face problems of the first and second types continues to confirm conviction in the importance of this variable in enabling the auditor to face the third type of problems (related to clients and departments). Therefore, we find that the rate of satisfaction about the ability of the first variable to provide the auditor the confidence to face this kind of problem is (0.829551), while the rate of non-acceptance is $(0.055417)$.

This conviction of the importance of the first variable (length of experience) in supporting the auditor in reducing the impact of problems of the three mentioned types of problems and reduce their bad effect on his performance 
clearly indicates the extent of the sample's conviction of the significance of the auditors' experience length provides strong immunity to auditors that enables them to deal with their professional problems they faces and enable them to limit its negative effects on his efficiency and neutrality.

This fact is also evident in the rates of satisfaction versus lack of contentment in the sample responses about the extent to which the first variable (length of experience) affects the nature of the fourth type problems that the auditor faces (behavioral aspects of colleagues and social pressures), as the rate of conviction indicates the importance of the first variable in reducing the impact of this type of problems on his efficiency and neutrality to (0.812603), while the rate of non-conviction was (0.065366). As it is clear, the gap between the rates of convictions states, which provides the conclusion that the auditors rely heavily on the experience length as one of the most important elements of the professional experience in assisting them to face the professional problems.

\section{2- Analysis of the Second Variable Rates:}

The Second variable of the auditor's professional experience is "the level of qualifications the auditor holds". The examination of the sample conviction about this variables as it is shown in rows (5-8) Table (2) indicates a conviction rate of (0.65435) and non conviction of (0.122494). Once again, theses rates give the impression that auditors give a high level of importance to the benefit taken from the second variable and its ability to assist auditors in facing the professional problems regarding the laws and legislation.

This result also indicates that the sample is convinced of the importance of the second variable in supporting the auditor in facing first kind of professional problem.

However, it is noticed that the rate of satisfaction with the ability of the second variable towards the first problem is less than the case of conviction with the first variable.

The same is indicated by the sample as regards the conviction related to the importance of the second variable in assisting auditor in facing the second kind of problems. The satisfaction average rate of this variable against the second kind of problems (related to professional societies and professional colleagues) is $(0.681801)$ while the rate of non-conviction about this importance was (0.100869). This conviction rate is considered highly important, although it is less than the conviction that resulted from the rates of the first variable.

The same direction is noticed in the sample auditors' answers where the rate of conviction about the importance of the second variable towards the third problem (related to customers and Managements) is (0.720775), while the rate of non conviction is (0.089439). This result indicates the same implication of the rates for the second problem. With regard to the fourth kinds of problems (behavioral aspects of professional colleagues and social pressures), the conviction rate reported is $(0.691614)$ and non conviction rate is $(0.090001)$. This result give the impression that auditors are certain about the significance of all the professional experience elements (variables ) in assisting them to face the professional problems.

\section{3- Analysis of the Third Variable Rates:}

Table No. (2) indicates the averages of conviction and non conviction about the third variable ( The nature of academic specialization), (rows 9-12) and its ability to support auditors facing the professional problems. The conviction rate towards the first kind of problems is (0.717307), and against the second kind of problems is (0.717307), and against the third kind of problems is (0.668619), for the fourth kind of problems is $(0.666153)$, while the non conviction rates came to be very low in comparison with the conviction rates giving the idea that there is a complete satisfaction of auditors about the significance of the auditors professional experience in supporting auditors to face the consequences of professional problems of different nature. 
For the purpose of showing the priority and likelihood of the variables in assisting auditors in facing the discussed problems, Table (3) show the final averages of conviction and non conviction of auditors towards the discussed problems.

Table No. (3)

The Sequence of the Three Variables According to Their Significance in Facing the Four Problems

\begin{tabular}{|c|c|c|c|}
\hline $\begin{array}{c}\text { Overall Approval Rate } \\
\text { For Each Variable }\end{array}$ & $\begin{array}{c}\text { Individual Approval } \\
\text { Rates }\end{array}$ & $\begin{array}{c}\text { Individual Rates of } \\
\text { Non-Approval }\end{array}$ & $\begin{array}{c}\text { Overall Non-Approval } \\
\text { Rate for Each Variable }\end{array}$ \\
\hline 0.81423 & 0.8954 & 0.02355 & 0.051955 \\
\hline & 0.71938 & 0.06348 & \\
\hline & 0.82955 & 0.05542 & 0.1007 \\
\hline 0.68714 & 0.8126 & 0.06537 & \\
\hline & 0.65435 & 0.12249 & \\
\hline & 0.6818 & 0.10087 & \\
\hline & 0.72078 & 0.08944 & \\
\hline & 0.69161 & 0.09 & \\
\hline & 0.78619 & 0.08151 & \\
\hline & 0.71731 & 0.08378 & \\
\hline
\end{tabular}

\section{The Results:}

Previous discussion of the questionnaire results and the information reflected by the Tables (1), (2), and (3) assist in testing the study hypotheses as follows:

1-All the study variables gain the auditors' confidence that these variables are important factors to support them in facing the problems of all kinds and reduce their effects on auditors' efficiency and neutrality .

2- The results indicated in Tables (1), (2), and (3) indicate that there is a great reliance of auditors that variable (1) has a great support to them in facing the problems (1-4) of all kinds. This should be taken into consideration when deciding how to qualify auditors for professional work.

3- For the purpose of comparing the three variables in terms of their importance to the sample in providing the auditor's ability to face the four problems, Table No. (3) shows the sub-rates of the effect of each variable with the general rate of the effect of the variable and for the three variables.

Based on what is mentioned above, we find that the sequence of importance of the variables in terms of their ability in supporting the auditor's ability to confront the problems facing him are as follows:

1- The first variable (the length of the auditor's experience) comes first, with a conviction rate (0.81423) and an objection rate (i.e., non- conviction) is (0.051955).

2- The third variable (the nature of the auditor's specialization) comes in second place with a conviction rate $(0.70957)$ and non conviction rate is (0.1024).

3- The second variable (the level of qualification held by the auditor and comes in third place with a conviction rate $(0.68714)$ and an objection or non-conviction rate $(0.1007)$. 
For this, Table No. (4) shows a summary of the sequence of the importance of the three variables (elements) of the auditor's professional experience in limiting the effects of problems that affect his work efficiency.

Table No. (4)

The Sequence of Variables Significance in Facing Audit Problems

\begin{tabular}{|l|l|c|c|}
\hline Sr. & \multicolumn{1}{|c|}{ Subject } & Approval & Non-Approval \\
\hline 1 & $\begin{array}{l}\text { The general effect of the experience period variable on the } \\
\text { four problems }\end{array}$ & 0.8954 & 0.02355 \\
\hline 2 & $\begin{array}{l}\text { The general effect of the qualification level variable on the } \\
\text { four problems }\end{array}$ & 0.65435 & 0.12249 \\
\hline 3 & $\begin{array}{l}\text { The general effect of the Specialization Field variable on } \\
\text { the Four problems }\end{array}$ & 0.70957 & 0.1024 \\
\hline
\end{tabular}

\section{Testing The Hypotheses:}

1- The analysis of the results and previous discussion indicate that there is a clear positive linear relationship between all the three variables of auditors' experience and its ability to reduce the negative effects on auditors. The results of the sample's opinions showed in Tables (1),(2) and (3) prove that the experience variables are very important to support auditors in their work. For this, the first hypothesis of the study (H0) is accepted, and the alternative hypothesis is rejected .

2- As regards the sub- hypothesis (HO1), the results indicated in Table (2), (3) and (4) clearly show the strength of the relationship between the variable No. (1) and the fourth problems the subject matter of this study. Thus the First sub- hypothesis No.(HO1) is accepted and the alternative hypothesis is rejected.

3- The same is to be said about the sub- hypothesis (HO2) where the discussion of the above mentioned tables indicate clearly the high rates of convictions about the significance of the second variable in assisting auditors. Thus the sub- hypothesis No.(HO2) is accepted and the alternative hypothesis is rejected.

4- The discussion of the same tables also proof the significance of the third experience variable in assisting auditors to face their professional work. The sub-hypothesis No. (HO3) assumes a statistically significant relationship between "the nature of the auditor's academic specialization" and the degree of reduction in the effect of the professional problems. Thus, the sub- hypothesis No. (HO3) is accepted and the alternative hypothesis is rejected.

\section{Conclusions and Recommendations}

\section{Conclusions:}

The study discussed an important topic about the auditors and their professional work and the problems they face. Studies have varied on the nature of these problems, their causes, and how to reduce their impact on auditors work. The study identified the features of auditors personality and found that auditors' professional experience as one of the best factors which would assist auditors to face theses problems and reduce their negative effects on their work .

The study paid careful attention to the importance of the elements of personal experience to reduce the problems facing auditors. The result indicated that all three elements (variables) of audit experience have a great benefit to assist auditors and reduce the impact of them on his work.

\section{Recommendations:}

For the purpose of achieving the goals of this study, it is recommended to follow the following points: 
1- Auditor's experience should be given more attention through developing the studies and courses he review. Also motivate auditors to join practical training, conferences, and meetings with foreign professional associations.

2- Paying attention to the auditor's training period prior to practicing the profession and emphasizing its seriousness, number of hours, and the experience of the audit office that conducts the training.

3- The auditor must periodically undergo tests of a nature that oblige him to familiarize himself with international experiences and how to face the problems surrounding him.

4- Spread global experiences in facing problems and methods of confrontation, and enhancing the auditor's experience in this field.

\section{References:}

[1] Al-Basheer, Mohammed",Accounting Profession and Future Challenges", The Auditor Magazine, No. 41,42, March 2000, Amman, Jordan.

[2] Al- Halaby Nabeel,'The Relation Between the Behavior of Functional failure and the Problems Facing Public Auditors", An Empirical Study, Irbid Magazine For Researches and Studies, Second Edition, No (1), pp. 124-140, Jordan. 1999.

[3] Al-Halabi, Nabil, “ The problems facing the auditing profession and their impact on the interest and confidence in the financial statements published by the Syrian private companies - a field study - Damascus University Journal of Economic and Legal Sciences - Volume (22) Issue (2) - 2006.

[4] Al-Fadal, Muaied, \& Al-JejawyTalal," " The evaluation of The Role of Accounting Education Textbooks in the Establishment of Vocational Skills-The Case of Iraq", A Paper submitted to the Second Accounting Professional Conference Held in Jordan, August 20-21, 2000, Amman, Jordan.

[5] Al- Khafash, Aadel Anwar ",Accounting profession In Arab countries facing the Twenty One Century's Challenges", TheArabic Accountants Magazine, June ,No.84, p. 28,1994.

[6] Al-Douri, Omar Ali Kamel , "The Historical Development of Auditing - An Economic and Political Perspective", The International Journal of Islamic Economy - Issue 26 - July 2014

[7] Al-Khater, Khaled Nasser, and Al-Attar, Jalal Muhammad, "An Analytical Study of the Auditing Profession in Qatar", Journal of Accounting, Management and Insurance (63) - 2004

[8] Al-Amro, Reem Omar Muhammad and Al-Anqari, Hussam Abdul-Mohsen, "Evaluation of the Effectiveness of the Pillars of Organizing the Profession of Auditing in the Kingdom of Saudi Arabia in Facing Contemporary Problems and Challenges - King Abdulaziz University Journal, Economics and Management, Volume (21) Issue (1) 2007.

[9] Al-Dalahma, SulaimanMustafa, "The Problems Facing the Practicing Legal Accountants in the Kingdom of Saudi Arabia", a field study, The Arab Journal of Accounting, Volume (9), Issue (1) - 2006.

[10] BasimaFaleh Al-Nuaimi, "Joint Auditing Between Implementation Difficulties and Improving Audit Performance - An Exploratory Study of the Views of Banking Managements and Account Auditors in the Kurdistan Region ,2006. Iraq," VolayZanist Scientific Journaal Lebanese French University-Kurdistan Iraq - Volume (5) Issue ( 2) Spring, (ISSN2518- 6566) - College of Humanities and Social Sciences - Koya University - Kurdistan. Iraq, 2020.

[11] -Coram Paul (2000), The Effect of Time Budget Pressure and Risk of Error On Auditor Performance Working Paper, University of Western Australia, 2000 .

[12] CHenock, P., "Fifteen Years of Meeting the Challenges", Journal of Accountancy (JAC), Vol.179, No.6, June pp. 66-70., 1995.

[13] Eynon, G., et al, "Perceptions of Sole Practitioners on Ethics Training in Profession", National Public Accountant, Vol. 41, No.4, 1996, pp.25-27.

[14] Helps ,L “,.Accountants; Higher Education; Profession Standards” ManagemenAccounting, London, Vol.72, 6,June,1994,p. 46.

[15] Jawdet, LutfyHameed, "Accounting Education In The Arab World-Problems and Solutions", A Paper submitted to the Second Accounting, Professional Conference Held in Jordan, August, 20-21, 2000, Amman, Jordan. 


\section{DOI: $10.51386 / 25815946 /$ ijsms-v4i3p108}

Volume: 4 Issue: 3

May to June 2021

www.ijsmsjournal.org

[16] Munir Shakir Mohommad and Abdul Naser I. Nour," “ The Influence of Personal Experience on the Problems Facing Publie Auditors in Jordan” ,Dirasat Journal for Administrative Sciences- University of Jordan, An International Refereed Research Journal, Volume 31, No.1, 2004.

[17] Mutter, Mohammed, "Current State of Accounting Profession in the Developing Countries and its Role in the Process of Economic Development", A Paper Submitted to the Second International Accounting Conference held in Jordan, 1990, the Conference Proceedings, pp.76-91.

[18] Mutter, Mohammed",There should be a change, the ways to improve the efficiency of Accounting Profession in Jordan", "TheArabic Accountants Magazine", January, No.87, 1994, pp. 3-30, Jordan.

[19] Maiala, Buttris, “ The Most Important Problems Facing Public Auditors In Syria”, Irbid Magazine for Researches and Studies, Irbid Private University, Second Group, No. 1, 1999, pp. 101-122, Jordan.

[20] Mohammed Saeed, Aras,"The Challenges Facing Accounting Educationin the Future”, A Paper submitted to the Second Accounting Professional Conference Held in Jordan,August 20-21, 2000, Amman, Jordan.

[21] Dargham, Maher , "Problems Facing Auditors in the Gaza Strip (Analytical)" -An-Najah University's Journal for Research (Human Sciences) - Volume 23, Issue (1), 2009.

[22] Marhoon, Naeem Toman, "The relationship between the problems of the auditing profession and the development of this profession in Iraq - an analytical and applied study" - Al-Qadisiyah University Journal of Administrative and Economic Sciences - Volume 14, Issue 2, year 2012.

[23] Marhoon, NaimToman, "The role of the financial authority and higher financial oversight bodies in the collection of income tax revenues in Iraq - An analytical and field study in the General Tax Authority - Diwaniyah branch and some auditors' offices, research presented to the first scientific conference - College of Administration and Economics - Al-Qadisiyah University - Volume One, 2009

[24] Thabet, Hassan Thabet and Abdel Wahid Ghazi Mohamed, "Challenges facing the external auditor in auditing fair value - a study of a sample of Iraqi auditing offices", International Forum on International Auditing Standards - On Activating the Performance of Institutions, 2012 .

\section{Appendix No. (1)}

Table No. (1)

Responses of the Study Sample about the Significance of the Study Independent Variables In Affecting Audit Problems

\begin{tabular}{|c|c|c|c|c|c|c|c|}
\hline Question & $\begin{array}{l}\text { Totally } \\
\text { agreed } \\
\text { (5) }\end{array}$ & $\begin{array}{l}\text { Agree } \\
\text { (4) }\end{array}$ & $\begin{array}{c}\text { Neutra } \\
1 \\
(3)\end{array}$ & $\begin{array}{r}\text { Not } \\
\text { Agreed } \\
(2)\end{array}$ & $\begin{array}{l}\text { Complet } \\
\text { ely } \\
\text { disagree } \\
\text { (1) }\end{array}$ & W.A & S.D \\
\hline $\begin{array}{c}\text { First Variable: Period Of Experience (P.E. } \\
\text { Section (1): problems related to laws and } \\
\text { legislation: }\end{array}$ & & & & & & & \\
\hline $\begin{array}{l}\text { (P.E.)reduces coordination problem between } \\
\text { auditors and the professional bodies. }\end{array}$ & $\begin{array}{r}36 \\
180\end{array}$ & $\begin{array}{l}10 \\
40\end{array}$ & $\begin{array}{l}2 \\
6\end{array}$ & $\begin{array}{l}0 \\
0\end{array}$ & 0 & 4.7083 & 1.096221751 \\
\hline $\begin{array}{l}\text { (P.E.)assists auditors to gain the professional } \\
\text { bodies confidence. }\end{array}$ & $\begin{array}{r}34 \\
170\end{array}$ & $\begin{array}{l}10 \\
40\end{array}$ & $\begin{array}{r}4 \\
12\end{array}$ & $\begin{array}{l}0 \\
0\end{array}$ & 0 & 4.625 & 1.132874333 \\
\hline $\begin{array}{l}\text { (P.E.)assists coordination between the auditors } \\
\text { and Management. }\end{array}$ & $\begin{array}{l}19 \\
95\end{array}$ & $\begin{array}{l}16 \\
64\end{array}$ & $\begin{array}{r}4 \\
12\end{array}$ & $\begin{array}{r}9 \\
18\end{array}$ & 0 & 3.9375 & 1.37283679 \\
\hline
\end{tabular}




\section{DOI: $\underline{10.51386 / 25815946 / i j s m s-v 4 i 3 p 108}$}

Volume: 4 Issue: 3

May to June 2021

www.ijsmsjournal.org

(P.E.)Help obtaining professional societies assistance .

(P.E.)assists Assist auditors to recognize law and legislations aims .

Section (2):Problems related to professional associations and professional colleagues:

(P.E.)Assist in reducing unfair competition among auditors.

(P.E.) provides experience that supports legal procedures for professional associations aiming to control the behavior of colleagues in the profession

(P.E.)helps reduce cases of unjustified abandonment of auditors from companies assigned to audit their accounts

P.E.)provides confidence to communicate with international associations and organizations concerned with the profession

(P.E.) helps reduce the cases of criticism among colleagues and the problems between them

\begin{tabular}{|c|c|c|c|c|c|c|}
\hline $\begin{array}{r}21 \\
105\end{array}$ & $\begin{array}{l}18 \\
72\end{array}$ & $\begin{array}{r}6 \\
18\end{array}$ & $\begin{array}{l}3 \\
6\end{array}$ & $\begin{array}{l}0 \\
0\end{array}$ & 4.1875 & 1.228907143 \\
\hline $\begin{array}{l}16 \\
80\end{array}$ & $\begin{array}{l}14 \\
56\end{array}$ & $\begin{array}{l}10 \\
30\end{array}$ & $\begin{array}{r}8 \\
16\end{array}$ & $\begin{array}{l}0 \\
0\end{array}$ & 3.7917 & 1.333049615 \\
\hline & & & & & & \\
\hline $\begin{array}{l}10 \\
50\end{array}$ & $\begin{array}{l}16 \\
64\end{array}$ & $\begin{array}{l}12 \\
36\end{array}$ & $\begin{array}{r}8 \\
16\end{array}$ & $\begin{array}{l}2 \\
2 \\
\end{array}$ & 3.5 & 1.333049615 \\
\hline 9 & 22 & 10 & 7 & 0 & \multirow{2}{*}{3.6875} & \multirow{2}{*}{1.206542449} \\
\hline 45 & 88 & 30 & 14 & 0 & & \\
\hline $\begin{array}{r}8 \\
40\end{array}$ & $\begin{array}{r}14 \\
56\end{array}$ & $\begin{array}{r}9 \\
27\end{array}$ & $\begin{array}{r}9 \\
18\end{array}$ & $\begin{array}{l}8 \\
8\end{array}$ & 3.1042 & 1.49452903 \\
\hline $\begin{array}{r}10 \\
50 \\
\end{array}$ & $\begin{array}{l}15 \\
60 \\
\end{array}$ & $\begin{array}{r}10 \\
30 \\
\end{array}$ & $\begin{array}{l}11 \\
22 \\
\end{array}$ & $\begin{array}{l}2 \\
2\end{array}$ & 3.4167 & 1.368956739 \\
\hline $\begin{array}{l}18 \\
90\end{array}$ & $\begin{array}{l}16 \\
64\end{array}$ & 8 & 10 & $\begin{array}{l}1 \\
1\end{array}$ & 3.9375 & 1.341482191 \\
\hline
\end{tabular}

\begin{tabular}{|c|c|c|c|c|c|c|c|}
\hline $\begin{array}{l}\text { Section Three: Problems related to the } \\
\text { relationship with clients and departments }\end{array}$ & & & & & & & \\
\hline $\begin{array}{l}\text { (P.E.) provides the departments with conviction of } \\
\text { the feasibility and benefits of auditing }\end{array}$ & $\begin{array}{r}20 \\
100\end{array}$ & $\begin{array}{l}18 \\
72\end{array}$ & $\begin{array}{r}6 \\
18\end{array}$ & $\begin{array}{l}4 \\
8\end{array}$ & 0 & 4.125 & 1.25409966 \\
\hline $\begin{array}{l}\text { (P.E.) helps persuade management not to interfere } \\
\text { with the content of the report's report. }\end{array}$ & $\begin{array}{l}17 \\
85\end{array}$ & $\begin{array}{l}17 \\
68\end{array}$ & $\begin{array}{r}6 \\
18\end{array}$ & $\begin{array}{r}6 \\
12\end{array}$ & $\begin{array}{r}2 \\
332\end{array}$ & 3.8542 & 1.402884566 \\
\hline $\begin{array}{l}\text { (P.E.) helps to increase management's cooperation } \\
\text { with the auditor and his assistants }\end{array}$ & $\begin{array}{l}14 \\
70\end{array}$ & $\begin{array}{l}19 \\
76\end{array}$ & $\begin{array}{l}10 \\
30\end{array}$ & $\begin{array}{r}5 \\
10\end{array}$ & $\begin{array}{l}0 \\
0\end{array}$ & 3.875 & 1.238392919 \\
\hline $\begin{array}{l}\text { (P.E.) helps in pushing the internal auditor in the } \\
\text { departments under audit to cooperate because they } \\
\text { feel the competence of the external auditor }\end{array}$ & $\begin{array}{l}16 \\
80\end{array}$ & $\begin{array}{l}16 \\
64\end{array}$ & $\begin{array}{r}9 \\
27\end{array}$ & 5 & 2 & 3.8125 & 1.37778731 \\
\hline
\end{tabular}




\section{DOI: $10.51386 / 25815946 /$ ijsms-v4i3p108}

Volume: 4 Issue: 3

May to June 2021

www.ijsmsjournal.org

(P.E.) helps gain clients' confidence and push them to deal with the audit results without being rejected.

\section{Section Four: Problems related to the behavioral aspects of colleagues and social} pressures:

(P.E.) helps motivate colleagues to develop cases of humanitarian cooperation and apply ethical evidence of work

(P.E.) helps motivate co-workers to develop the work methods and methodologies used

(P.E.) helps support co-workers to build mutual trust in them

(P.E.) helps with social pressures to change the results of the audit report

(P.E.)helps with management pressure to change the results of the audit report

\begin{tabular}{|c|c|c|c|c|c|c|}
\hline $\begin{array}{l}17 \\
85\end{array}$ & $\begin{array}{l}21 \\
84\end{array}$ & $\begin{array}{r}5 \\
15\end{array}$ & $\begin{array}{l}3 \\
6\end{array}$ & $\begin{array}{l}2 \\
2\end{array}$ & 4 & 1.326649916 \\
\hline & & & & & & \\
\hline $\begin{array}{r}22 \\
110\end{array}$ & $\begin{array}{l}19 \\
76\end{array}$ & $\begin{array}{r}4 \\
12\end{array}$ & $\begin{array}{l}3 \\
6\end{array}$ & $\begin{array}{l}0 \\
0\end{array}$ & 4.25 & 1.217601409 \\
\hline $\begin{array}{l}12 \\
60\end{array}$ & $\begin{array}{l}14 \\
56\end{array}$ & $\begin{array}{l}10 \\
30\end{array}$ & $\begin{array}{r}8 \\
16\end{array}$ & $\begin{array}{l}4 \\
4\end{array}$ & 3.4583 & 1.450458475 \\
\hline $\begin{array}{l}19 \\
95\end{array}$ & $\begin{array}{l}18 \\
72\end{array}$ & $\begin{array}{r}7 \\
21\end{array}$ & $\begin{array}{l}4 \\
8\end{array}$ & $\begin{array}{l}0 \\
0\end{array}$ & 4.0833 & 1.252062129 \\
\hline$\frac{15}{75}$ & $\frac{15}{60}$ & $\frac{10}{30}$ & 10 & 3 & 3.7083 & 1.416618689 \\
\hline $\begin{array}{l}18 \\
90\end{array}$ & $\begin{array}{l}18 \\
72\end{array}$ & $\begin{array}{r}6 \\
18\end{array}$ & $\begin{array}{r}6 \\
12\end{array}$ & 0 & 4 & 1.294176811 \\
\hline
\end{tabular}

\section{Second variable: the level of Aacademic Qualification(LAQ):}

\section{The First section: Problems related to laws and} legislation:

(LAQ)helps reduce the problems of coordination between the auditor and the professional associations and unions organizing the profession

(LAQ)helps in gaining the confidence of the professional societies on the attention required by the professional societies for the work of the auditor

\begin{tabular}{|c|c|c|c|c|c|c|}
\hline auditor & 50 & 16 & 33 & 10 & 3 & \\
\hline $\begin{array}{l}\text { (LAQ) helps in developing and changing the laws } \\
\text { and regulations governing the profession }\end{array}$ & $\begin{array}{l}7 \\
35\end{array}$ & $\begin{array}{l}19 \\
76\end{array}$ & $\begin{array}{l}12 \\
36\end{array}$ & $\begin{array}{l}9 \\
18\end{array}$ & $\begin{array}{l}1 \\
1\end{array}$ & 3.4583 \\
\hline $\begin{array}{l}\text { (LAQ) helps him obtain his right to discuss the } \\
\text { issue of his exclusion from the work he is assigned } \\
\text { to }\end{array}$ & $\begin{array}{l}7 \\
35\end{array}$ & 11 & $\begin{array}{l}12 \\
36\end{array}$ & $\begin{array}{l}12 \\
24\end{array}$ & 6 & 3.0208 \\
\hline
\end{tabular}




\section{DOI: $10.51386 / 25815946 /$ ijsms-v4i3p108}

Volume: 4 Issue: 3

\begin{tabular}{|c|c|c|c|c|c|c|c|}
\hline $\begin{array}{l}\text { (LAQ) helps him obtain the care and attention he } \\
\text { receives from government departments }\end{array}$ & $\begin{array}{l}8 \\
40\end{array}$ & $\begin{array}{l}12 \\
48\end{array}$ & $\begin{array}{l}15 \\
45\end{array}$ & $\begin{array}{l}10 \\
20\end{array}$ & $\begin{array}{l}3 \\
3\end{array}$ & 3.25 & 1.331132936 \\
\hline \multicolumn{8}{|l|}{$\begin{array}{l}\text { Section Two: Section Two: Problems related to } \\
\text { professional associations and professional } \\
\text { colleagues: }\end{array}$} \\
\hline $\begin{array}{l}\text { (LAQ) helps reduce unfair competition among } \\
\text { auditors. }\end{array}$ & $\begin{array}{l}14 \\
70\end{array}$ & $\begin{array}{l}15 \\
60\end{array}$ & $\begin{array}{l}12 \\
36\end{array}$ & $\begin{array}{l}7 \\
14\end{array}$ & $\begin{array}{l}0 \\
0\end{array}$ & 3.6 & 1.288244724 \\
\hline $\begin{array}{l}\text { (LAQ) helps in strengthening the legal procedures } \\
\text { of professional societies that aim to control the } \\
\text { behavior of colleagues in the profession }\end{array}$ & $\begin{array}{l}11 \\
55\end{array}$ & $\begin{array}{l}15 \\
60\end{array}$ & $\begin{array}{l}13 \\
39\end{array}$ & 7 & 2 & 3.4 & 1.33687473 \\
\hline $\begin{array}{l}\text { (LAQ) helps reduce cases of unjustified } \\
\text { abandonment of the auditors from the companies } \\
\text { assigned to audit their accounts }\end{array}$ & $\begin{array}{l}10 \\
50\end{array}$ & $\begin{array}{l}12 \\
48\end{array}$ & $\begin{array}{l}15 \\
45\end{array}$ & 7 & $\begin{array}{l}4 \\
4\end{array}$ & 3.22 & 1.388248552 \\
\hline $\begin{array}{l}\text { (LAQ) helps to encourage communication with } \\
\text { international associations and organizations } \\
\text { concerned with the profession }\end{array}$ & $\begin{array}{l}11 \\
55\end{array}$ & $\begin{array}{l}14 \\
56\end{array}$ & $\begin{array}{l}11 \\
33\end{array}$ & 9 & $\begin{array}{l}3 \\
3\end{array}$ & 3.3 & 1.402884566 \\
\hline $\begin{array}{l}\text { (LAQ) helps reduce the cases of criticism among } \\
\text { colleagues in the profession and the problems } \\
\text { between them }\end{array}$ & $\begin{array}{l}11 \\
55\end{array}$ & $\begin{array}{l}15 \\
70\end{array}$ & $\begin{array}{l}12 \\
36\end{array}$ & $\begin{array}{l}7 \\
14\end{array}$ & $\begin{array}{l}3 \\
3\end{array}$ & 3.56 & 1.380101754 \\
\hline \multicolumn{8}{|l|}{$\begin{array}{l}\text { Section Three: Problems related to the } \\
\text { relationship with clients and departments } \\
\end{array}$} \\
\hline $\begin{array}{l}\text { (LAQ) helps to reduce the state of failure of the } \\
\text { departments to the feasibility and benefits of } \\
\text { auditing }\end{array}$ & $\begin{array}{l}12 \\
60\end{array}$ & $\begin{array}{l}16 \\
64\end{array}$ & $\begin{array}{l}11 \\
33\end{array}$ & $\begin{array}{l}8 \\
16\end{array}$ & 1 & 3.625 & 1.324723978 \\
\hline $\begin{array}{l}\text { (LAQ)helps persuade management not to interfere } \\
\text { with the content of the report. }\end{array}$ & $\begin{array}{l}11 \\
55\end{array}$ & $\begin{array}{l}18 \\
72\end{array}$ & $\begin{array}{l}12 \\
36\end{array}$ & $\begin{array}{l}7 \\
14\end{array}$ & $\begin{array}{l}0 \\
0\end{array}$ & 3.687 & 1.241310221 \\
\hline $\begin{array}{l}\text { (LAQ)helps in increasing the management's } \\
\text { cooperation with the auditor and his assistants }\end{array}$ & $\begin{array}{l}10 \\
50\end{array}$ & $\begin{array}{l}15 \\
70\end{array}$ & $\begin{array}{l}15 \\
45\end{array}$ & $\begin{array}{l}8 \\
16\end{array}$ & 0 & 3.770 & 1.239251662 \\
\hline $\begin{array}{l}\text { (LAQ)motivates internal auditors to cooperate } \\
\text { because they feel reassured. }\end{array}$ & $\begin{array}{l}14 \\
70\end{array}$ & $\begin{array}{l}14 \\
56\end{array}$ & $\begin{array}{l}13 \\
39\end{array}$ & $\begin{array}{l}7 \\
14\end{array}$ & $\begin{array}{l}0 \\
0\end{array}$ & 3.729 & 1.289730303 \\
\hline $\begin{array}{l}\text { (LAQ)helps in gaining the confidence of clients } \\
\text { and pushing them to deal with the audit results } \\
\text { without rejection. }\end{array}$ & $\begin{array}{l}18 \\
90\end{array}$ & $\begin{array}{l}18 \\
72\end{array}$ & $\begin{array}{l}10 \\
30\end{array}$ & $\begin{array}{l}2 \\
4\end{array}$ & 0 & 4.083 & 1.2 \\
\hline
\end{tabular}




\section{DOI: $10.51386 / 25815946 /$ ijsms-v4i3p108}

Volume: 4 Issue: 3

\begin{tabular}{|c|c|c|c|c|c|c|c|}
\hline $\begin{array}{l}\text { Section Four: Problems related to the } \\
\text { behavioral aspects of colleagues and social } \\
\text { pressures: }\end{array}$ & & & & & & & \\
\hline $\begin{array}{l}\text { (LAQ)helps motivate colleagues to develop cases } \\
\text { of human cooperation and apply ethical evidence } \\
\text { of work }\end{array}$ & $\begin{array}{l}12 \\
60\end{array}$ & $\begin{array}{l}12 \\
48\end{array}$ & $\begin{array}{l}12 \\
36\end{array}$ & 9 & 3 & 3.4375 & 1.41796978 \\
\hline $\begin{array}{l}\text { (LAQ)helps motivate co-workers to develop the } \\
\text { work methods and methodologies used }\end{array}$ & $\begin{array}{l}11 \\
55\end{array}$ & $\begin{array}{l}15 \\
60\end{array}$ & $\begin{array}{l}13 \\
39\end{array}$ & $\begin{array}{l}9 \\
18\end{array}$ & 0 & 3.5833 & 1.274295801 \\
\hline $\begin{array}{l}\text { (LAQ)helps support coworkers to build mutual } \\
\text { trust in them }\end{array}$ & $\begin{array}{l}14 \\
70\end{array}$ & $\begin{array}{l}15 \\
60\end{array}$ & $\begin{array}{l}14 \\
42\end{array}$ & $\begin{array}{l}5 \\
10\end{array}$ & $\begin{array}{l}0 \\
0\end{array}$ & 3.7917 & 1.250701931 \\
\hline $\begin{array}{l}\text { (LAQ)helps in facing social pressures aiming to } \\
\text { change the results of the audit report }\end{array}$ & $\begin{array}{l}15 \\
75\end{array}$ & $\begin{array}{l}15 \\
60\end{array}$ & $\begin{array}{l}12 \\
36\end{array}$ & $\begin{array}{l}6 \\
12\end{array}$ & 0 & 3.8125 & 1.281787316 \\
\hline $\begin{array}{l}\text { (LAQ)helps in facing the pressures of the } \\
\text { administration aiming to change the results of the } \\
\text { audit report }\end{array}$ & $\begin{array}{l}14 \\
70\end{array}$ & $\begin{array}{l}13 \\
42\end{array}$ & $\begin{array}{l}12 \\
36\end{array}$ & $\begin{array}{l}7 \\
14\end{array}$ & $\begin{array}{l}2 \\
2\end{array}$ & 3.4167 & 1.38748203 \\
\hline
\end{tabular}

\begin{tabular}{|c|c|c|c|c|c|c|c|}
\hline $\begin{array}{c}\text { Third variable: Nature of the Scientific } \\
\text { Specialty (S.S)of the auditor. } \\
\text { First Section: Problems related to laws and } \\
\text { Legislation: }\end{array}$ & & & & & & & \\
\hline $\begin{array}{l}\text { (S.S) reduce the problems of coordination between } \\
\text { the auditor and the professional associations and } \\
\text { unions organizing the profession }\end{array}$ & $\begin{array}{l}12 \\
60\end{array}$ & $\begin{array}{l}19 \\
76\end{array}$ & $\begin{array}{l}8 \\
24\end{array}$ & $\begin{array}{l}8 \\
16\end{array}$ & 1 & 3.6875 & 1.324242055 \\
\hline $\begin{array}{l}\text { (S.S) helps in the interest required by professional } \\
\text { societies in the work of the auditor. }\end{array}$ & $\begin{array}{l}14 \\
70\end{array}$ & $\begin{array}{l}21 \\
84\end{array}$ & $\begin{array}{l}7 \\
21\end{array}$ & $\begin{array}{l}6 \\
12\end{array}$ & 0 & 3.8958 & 1.251552228 \\
\hline $\begin{array}{l}\text { (S.S) helps in developing and changing the laws } \\
\text { and instructions regulating the profession }\end{array}$ & $\begin{array}{l}12 \\
60\end{array}$ & $\begin{array}{l}20 \\
80\end{array}$ & $\begin{array}{l}8 \\
24\end{array}$ & $\begin{array}{l}6 \\
12\end{array}$ & 2 & 3.7083 & 1.339418737 \\
\hline \multirow[t]{2}{*}{$\begin{array}{l}\text { (S.S)helps him obtain his right to discuss the issue } \\
\text { of his exclusion from the work assigned to him }\end{array}$} & 8 & 16 & 9 & 9 & 6 & \multirow{2}{*}{3.2292} & \multirow{2}{*}{1.447668705} \\
\hline & 40 & 64 & 27 & 18 & 6 & & \\
\hline $\begin{array}{l}\text { (S.S)helps in obtaining the care and attention he } \\
\text { receives from government departments }\end{array}$ & $\begin{array}{l}15 \\
75\end{array}$ & $\begin{array}{l}21 \\
84\end{array}$ & $\begin{array}{l}6 \\
18\end{array}$ & $\begin{array}{l}6 \\
12\end{array}$ & 0 & 3.9375 & 1.259685878 \\
\hline $\begin{array}{l}\text { Section Two: Section Two: Problems related to } \\
\text { professional associations and professional } \\
\text { colleagues: }\end{array}$ & & & & & & & \\
\hline
\end{tabular}




\begin{tabular}{|c|c|c|c|c|c|c|c|}
\hline $\begin{array}{l}\text { (S.S)helps reduce unfair competition among } \\
\text { auditors. }\end{array}$ & $\begin{array}{l}6 \\
30\end{array}$ & $\begin{array}{l}17 \\
68\end{array}$ & $\begin{array}{l}14 \\
42\end{array}$ & $\begin{array}{l}8 \\
16\end{array}$ & $\begin{array}{l}3 \\
3\end{array}$ & 3.3125 & 1.283114562 \\
\hline $\begin{array}{l}\text { (S.S)helps in strengthening the legal procedures of } \\
\text { professional societies that aim to control the } \\
\text { behavior of colleagues in the profession }\end{array}$ & 7 & $\begin{array}{l}17 \\
68\end{array}$ & $\begin{array}{l}15 \\
45\end{array}$ & $\begin{array}{l}6 \\
12\end{array}$ & 3 & 3.3958 & 1.28510286 \\
\hline $\begin{array}{l}\text { (S.S)helps reduce cases of unjustified } \\
\text { abandonment of the auditors from the companies } \\
\text { charged with auditing their accounts }\end{array}$ & 8 & $\begin{array}{l}18 \\
72\end{array}$ & $\begin{array}{l}15 \\
45\end{array}$ & 5 & 2 & 3.5208 & 1.252911503 \\
\hline $\begin{array}{l}\text { (S.S)helps to encourage communication with } \\
\text { international associations and organizations } \\
\text { concerned with the profession }\end{array}$ & $\begin{array}{l}19 \\
95\end{array}$ & $\begin{array}{l}18 \\
72\end{array}$ & $\begin{array}{l}6 \\
18\end{array}$ & $\begin{array}{l}5 \\
10\end{array}$ & 0 & 4.0625 & 1.275797623 \\
\hline $\begin{array}{l}\text { (S.S)helps reduce cases of criticism among } \\
\text { colleagues in the profession and the problems } \\
\text { between them }\end{array}$ & $\begin{array}{l}18 \\
90\end{array}$ & $\begin{array}{l}16 \\
64\end{array}$ & $\begin{array}{l}6 \\
18\end{array}$ & $\begin{array}{l}8 \\
16\end{array}$ & $\begin{array}{l}0 \\
0\end{array}$ & 3.9167 & 1.345757716 \\
\hline \multicolumn{8}{|l|}{$\begin{array}{l}\text { Section Three: Problems related to the } \\
\text { relationship with clients and departments }\end{array}$} \\
\hline $\begin{array}{l}\text { (S.S)helps to reduce the state of non-conviction of } \\
\text { departments in the feasibility and benefits of } \\
\text { auditing }\end{array}$ & $\begin{array}{l}4 \\
20\end{array}$ & $\begin{array}{l}16 \\
64\end{array}$ & $\begin{array}{l}14 \\
42\end{array}$ & $\begin{array}{l}8 \\
16\end{array}$ & $\begin{array}{l}6 \\
6\end{array}$ & 3.0833 & 1.320219195 \\
\hline $\begin{array}{l}\text { (S.S)helps persuade the management not to } \\
\text { interfere with the content of the report. }\end{array}$ & $\begin{array}{l}3 \\
15\end{array}$ & $\begin{array}{l}17 \\
68\end{array}$ & $\begin{array}{l}14 \\
42\end{array}$ & $\begin{array}{l}7 \\
14\end{array}$ & $\begin{array}{l}7 \\
7\end{array}$ & 3.0417 & 1.318283862 \\
\hline $\begin{array}{l}\text { (S.S)helps in increasing the management's } \\
\text { cooperation with the auditor and his assistants }\end{array}$ & $\begin{array}{l}11 \\
55\end{array}$ & $\begin{array}{l}18 \\
72\end{array}$ & $\begin{array}{l}10 \\
30\end{array}$ & $\begin{array}{l}7 \\
14\end{array}$ & $\begin{array}{l}2 \\
2\end{array}$ & 3.6042 & 1.340212749 \\
\hline $\begin{array}{l}\text { (S.S) helps in pushing the internal auditor in the } \\
\text { departments under audit to cooperate because they } \\
\text { feel reassured. }\end{array}$ & $\begin{array}{l}10 \\
50\end{array}$ & $\begin{array}{l}15 \\
60\end{array}$ & 33 & 9 & $\begin{array}{l}3 \\
3\end{array}$ & 3.4167 & 1.384411696 \\
\hline $\begin{array}{l}\text { (S.S)helps in gaining the confidence of clients and } \\
\text { pushing them to deal with the results of the audit } \\
\text { without rejection. }\end{array}$ & $\begin{array}{l}14 \\
70\end{array}$ & $\begin{array}{l}19 \\
76\end{array}$ & $\begin{array}{l}9 \\
27\end{array}$ & $\begin{array}{l}4 \\
8\end{array}$ & $\begin{array}{l}1 \\
1\end{array}$ & 3.7917 & 1.380101754 \\
\hline \multicolumn{8}{|l|}{$\begin{array}{l}\text { Section Four: Problems related to the } \\
\text { behavioral aspects of colleagues and social } \\
\text { pressures: }\end{array}$} \\
\hline $\begin{array}{l}\text { (S.S)helps in pushing colleagues to develop cases } \\
\text { of human cooperation and to apply ethical } \\
\text { evidence of work }\end{array}$ & $\begin{array}{l}8 \\
40\end{array}$ & $\begin{array}{l}18 \\
72\end{array}$ & 9 & 9 & $\begin{array}{l}4 \\
4\end{array}$ & 3.3542 & 1.388248552 \\
\hline $\begin{array}{l}\text { (S.S)helps in pushing co-workers to develop the } \\
\text { methods and methodologies of work used }\end{array}$ & $\begin{array}{l}6 \\
30\end{array}$ & $\begin{array}{l}17 \\
68\end{array}$ & $\begin{array}{l}10 \\
30\end{array}$ & $\begin{array}{l}12 \\
24\end{array}$ & $\begin{array}{l}3 \\
3\end{array}$ & 3.2292 & 1.324884579 \\
\hline
\end{tabular}




\section{DOI: $\underline{10.51386 / 25815946 / i j s m s-v 4 i 3 p 108}$}

Volume: 4 Issue: 3

\begin{tabular}{|c|c|c|c|c|c|c|c|}
\hline \multirow{2}{*}{$\begin{array}{l}\text { (S.S)helps support coworkers to build mutual trust } \\
\text { in them }\end{array}$} & 8 & 18 & 10 & 8 & 4 & \multirow{2}{*}{3.375} & \multirow{2}{*}{1.377014965} \\
\hline & 40 & 72 & 30 & 16 & 4 & & \\
\hline $\begin{array}{l}\text { (S.S)helps in facing social pressures aimed at } \\
\text { changing the results of the audit report }\end{array}$ & $\begin{array}{l}5 \\
25\end{array}$ & $\begin{array}{l}17 \\
68\end{array}$ & $\begin{array}{l}13 \\
39\end{array}$ & $\begin{array}{l}9 \\
18\end{array}$ & 4 & 3.2083 & 1.302044219 \\
\hline $\begin{array}{l}\text { (S.S)helps in facing the pressures of the } \\
\text { administration aimed at changing the results of the } \\
\text { audit report }\end{array}$ & 9 & $\begin{array}{l}19 \\
68\end{array}$ & $\begin{array}{l}12 \\
36\end{array}$ & $\begin{array}{l}6 \\
12\end{array}$ & 2 & 3.3958 & 1.289730303 \\
\hline
\end{tabular}

